\title{
ASTP: MODEL PEMBELAJARAN BAHASA ASING BAGI MILITER
}

\author{
A. Sayuti Anshari Nasution \\ Fakultas Ilmu Tarbiah dan Keguruan, UIN Syarif Hidayatullah Jakarta \\ Email. asnasution2002@yahoo.com
}

\begin{abstract}
The United States Army during the Second World War stunned the education world with their foreign language teaching experience. Their program that is called "The Army Specialized Training Program" (ASTP) was able to successfully train many participants with a very high success rate. Dr. Hamada Ibrahim, a professor in foreign languages at Cairo University, Egypt, described the "ASTP" as the most immense and successful program of learning foreign language in the history. The US Army foreign language program encompasses the background for the emergence of this program, a general picture of the program, the teaching subjects as well as the teaching techniques.
\end{abstract}

Keywords

ASTP, Foreign Language, Army Method, ASTP

\section{Pendahuluan}

Pembelajaran bahasa asing, tampaknya bukan saja "monopoli" dari institusi pendidikan sipil, institusi militerpun ternyata sukses menggelutinya. Angkatan Bersenjata Amerika Serikat, umpamanya mempunyai pengalaman yang tidak dapat dilupakan oleh sejarah pengajaran bahasa asing sepanjang masa.

Dr. Hamada Ibrahim, seorang guru besar pengajaran bahasa asing di Cairo University, Mesir mendeskripsikan program pembelajaran bahasa asing yang diselenggarakan oleh The Army Specialized Traning Program (ASTP) ini sebagai program yang paling sukses dan paling besar sepanjang sejarah pengajaran bahasa asing. (Ibrahim, 2007:61)

Sukses besar yang telah dicapai oleh angkatan bersenjata Amerika Serikat menjelang perang dunia ke II terlaksana dengan kerja keras penyelenggaranya, yaitu The Army Specialized Traning Program (ASTP), sebuah lembaga di lingkungan Departemen Pertahanan Amerika yang sengaja dibentuk untuk melaksanakan program pengajaran bahasa asing untuk prajurit angkatan bersenjata Amerika Serikat.

Pelatihan intensif bahasa asing ini sengaja diselenggarakan dengan tujuan agar setiap anggota militer Amerika Serikat yang mengikuti program dapat menguasai paling tidak sebuah bahasa asing dalam jangka waktu yang sudah ditetapkan ( \pm 6 bulan) dan pada gilirannya diharapkan dapat mendukung tercapainya tujuan angkatan bersenjata Amerika Serikat untuk dapat berkomunikasi dengan warga setempat dengan menggunakan bahasa negara yang menjadi target ekspansi ketika mereka diterjunkan ke negara tersebut di perang dunia ke II. 
Penguasaan bahasa setempat oleh prajurit angkatan bersenjata Amerika Serikat ini ditetapkan menjadi tujuan utama dan terutama dalam program ini antara lain adalah sebagai upaya untuk menutupi kelemahan angkatan bersenjata Amerika Serikat pasca perang dunia I, dimana sebuah pengalaman pahit harus mereka terima akibat tidak mampu berkomunikasi atau berbahasa dengan bahasa setempat negara ekspansinya. Pasukan Amerika Serikat yang sudah berhasil menaklukkan dan menduduki beberapa negara, namun dalam waktu yang tidak terlalu lama, angkatan bersenjata Amerika Serikat tersebut terpaksa angkat kaki, diusir dari negara tersebut, karena para militer Amerika Sertikat tidak bisa berkomunikasi dengan baik dengan rakyat setempat, sehingga penduduk negara tersebut tetap menganggap mereka sebagai penjajah yang harus diusir.

Apa dan bagaimana sebenarnya sistem pembelajaran bahasa asing yang pernah dipraktekkan oleh The Army Specialized Traning Program tersebut sehingga ia termuat di dalam kajian-kajian metode pembelajaran bahasa asing. Hal ini yang akan didiskripsikan pada tulisan ini.

\section{ASTP dan Pengajaran Bahasa Asing.}

Pengajaran bahasa Asing bukanlah produk abad 20 ini, akan tetapi sudah ada dari sejak lama,

bahkan sejak dari zaman Yunani kuno pengajaran bahasa asing ini sudah muncul dengan

berbagai metode dan pendekatannya. Muljanto Sumardi (1975) menyebutkan perkembangan

historis pengajaran bahasa dapat diklasifikasikan kepada lima periode. Pertama, periode

Romawi Kuno dan Abad Pertengahan. Kedua, Periode Renaisance. Ketiga, Periode Abad ke-

17 dan 18. Keempat, Periode Abad ke-19. Kelima, Periode Abad ke-20.

Perkembangan metode pengajaran bahasa asing memang tidak terlepas dari perkembangan

zaman dan tuntutan politik suatu negara. Ketika tuntutan masa di suatu negara ingin

menghidupkan bahasa-bahasa asing yang sudah mati, maka metode tata bahasa pun populer

dalam pengajaran bahasa di kala itu, karena dianggap lebih sesuai dengan tujuan yang

diinginkan. Akan tetapi ketika masa menghendaki agar lulusan dapat menerjemahkan hasil-

hasil karya yang tertulis dalam bahasa asing, maka metode pertama dianggap tidak relevan

lagi, maka muncul metode baru yang dalam hal ini metode terjemah dianggap lebih sesuai

untuk saat itu. Bila zaman menuntut agar lulusan dapat berkomunikasi aktif menggunakan

bahasa asing, maka metode langsungpun populer untuk menjawab tuntutan zaman.

Demikianlah kondisi di saat menjelang perang dunia ke II, angkatan bersenjata Amerika 
Serikat menuntut agar prajurit dapat berbahasa sesuai dengan bahasa target ekspansinya sehingga pada akhirnya mereka pun melahirkan sebuah metode yang lebih sesuai untuk tujuan itu. Dalam kaitan ini rasanya sangat relevan menyebutkan secara singkat perkembangan metode pengajaran bahasa asing di negara maju, masing-masing di Amerika Serikat dan Inggris sebagai pendukung tesis di atas.

Di Amerika Serikat, khususnya setelah zaman Renaisance, perhatian para ilmuan dan praktisi bahasa terhadap metode pengajaran bahasa asing jelas terlihat. Pada tahun 1892, Tim Committee of Twelve yang tergabung di lembaga Modern Language Association of Amerika (Himpunan Bahasa Modern Amerika) menyampaikan rekomendasi berupa konsep tentang pembelajaran bahasa kepada National Education Association (Himpunan Pendidikan Nasional) di Amerika yang pada intinya pengajaran bahasa harus sampai pada mempelajari budaya bangsa penutur bahasa tersebut. Sebagaimana yang dikutip oleh Muljanto Sumardi (1975:25-26), kemampuan bercakap-cakap saja tidak boleh dianggap sebagai sesuatu yang sangat penting tetapi sebagai alat bantu untuk mencapai kemahiran bahasa dan sastra-budaya yang lebih tinggi lagi. Sebagai tindak lanjut dari rekomendasi ini lahir Metode Tatabahasa dan Terjemah atau Grammar-Translation Method, sebuah metode yang merupakan kombinasi antara metode gramatika dan metode terjemah (Dahlan, 1992: 114). Metode ini sekaligus meninggalkan Metode Langsung yang sudah populer sejak kelahirannya pada tahun $1880 \mathrm{di}$ Prancis. Metode Tatabahasa dan Terjemah ini kemudian ditinggalkan oleh Metode Reformulasi (Reform Method) yang konon berasal dari Eropa sebagai respon terhadap meningkatnya permintaan dan minat masyarakat terhadap bahasa lisan yang lebih komunikatif.. 
Antara tahun 1899-1924, metode yang populer di Inggris, adalah Metode Langsung atau Direct Method yaitu sebuah metode pembelajaran bahasa asing dimana guru langsung menggunakan bahasa target tidak memakai bahasa perantara (bahasa siswa) selama proses belajar berlangsung (Al-Araby, 2001:41; Yusuf, 1995:50). Metode ini pernah tercatat sebagai metode yang paling populer, akan tetapi akhirnya ditinggalkan dan berpindah kepada metode lain yang dianggap lebih cocok.

Dari keterangan di atas, bisa terlihat dengan jelas, bahwa ASTP bukanlah barang baru dalam pembelajaran bahasa asing, tetapi program ini merupakan satu mata rantai dari metode pembelajaran bahasa asing yang telah berkembang dari sejak lama. Metode ini merupakan kelanjutan dari metode-metode yang sudah ada yang direvisi agar sesuai dengan tuntuan zaman pada masa itu, tentunya tidak mustahil juga kelak akan ada metode yang akan merevisi metode ini.

\section{Latar Belakang ASTP}

Menjelang Perang Dunia II, Amerika Serikat menyadari betapa kurangnya kemampuan angkatan darat, angkatan laut dan angkatan udara Amerika Serikat di bidang penguasaan bahasa asing yang berimbas pada pengusiran semua angkatan bersenjata Amerika yang sudah tersebar di berbagai penjuru dunia. Dari pengalaman ini, pimpinan angkatan bersenjata Amerika Serikat berupaya membuat sebuah program pembelajaran bahasa asing yang akan diberikan kepada para personilnya yang akan diterjunkan dalam perang dunia ke II ke berbagai target ekspansi supaya mereka mampu menguasai bahasa setempat (Al-Qasimi, 1999:67).

Sebagai institusi militer yang minim pengalaman pengajaran bahasa tentu mendapat banyak kesulitan dalam merealisasi tujuan ini. Namun dengan bantuan dari beberapa universitas 
ternama di Amerika, angkatan bersenjata Amerika Serikat berhasil mendirikan sebuah sekolah

khusus bahasa yang tunduk di bawah manejemen dari Army Specialized Training Program

(ASTP). Melalui institusi baru ini program pelatihan bahasa asing bagi prajurit angkatan

bersenjata Amerika Serikat dilaksanakan.

Bila tujuan pelatihan ini berhasil, maka komunikasi yang efektif antara prajurit Amerika

Serikat dengan warga di setiap negara yang didudukinya diharapkan dapat tercipta dan pada

gilirannya akan dapat menunjang tercapainya sebuah target strategis yaitu kelanggengan

keberadaan pasukan Amerika Serikat di negara yang telah didudukinya. Dengan demikian,

maka pembuatan program ini diharapkan menjadi kontribusi besar dari Angkatan Bersenjata

Amerika dalam merealisasi ambisi Amerika Serikat untuk menguasai dunia tanpa kendala

bahasa serta menghindari jangan sampai pengalaman pasca perang dunia I terulang kembali.

\section{Gambaran Umum Program ASTP}

Program ini untuk pertama kalinya direncanakan pada bulan April Tahun 1943 dengan jumlah peserta mencapai 15.000 prajurut yang sudah lulus seleksi. Jumlah bahasa asing yang akan diajarkan mencapai 17 bahasa, sesuai dengan jumlah daerah target operasi yang telah direncanakan oleh Amerika Serikat. Peserta pelatihan dibagi kepada beberapa kelompok. Setiap kelompok tidak lebih dari 10 orang. Satu orang guru bertanggung jawab maksimal terhadap 2 kelompok dan setiap 8 kelompok diawasi oleh seorang supervisor. (Hammada Ibrahim, 2007, 61) Dari data di atas, dapat ditaksir, bahwa jumlah lokal yang harus tersedia minimal 1.500 lokal sedangkan jumlah tutor dan guru yang harus tersedia minimal 750 tutor dan 750 guru serta jumlah supervisor yang harus tersedia minimal 188 supervisor. Proses belajar mengajar di sekolah ini dilakukan secara intensif dan non-stop, sepanjang hari, sehingga hanya dalam beberapa bulan saja hasilnya sudah terlihat.

Walaupun sudah mulai direncanakan sejak April 1943, namun program ini baru dapat terealisasi untuk pertama kalinya setelah 10 bulan, yaitu pada bulan Pebruari tahun 1944. Hal ini sangat logis mengingat program itu membutuhkan persiapan yang cukup matang dan waktu yang tidak sebentar. Menurut rencana, pelatihan ini akan memakan waktu sekitar 180 sampai 279 hari (6 sampai 9 bulan). Setelah 6 minggu program dilaksanakan, panitia pelaksana mengadakan survei ke lapangan, mereka mengadakan tatap muka dengan para peserta dan berdiskusi dengan para tutor yang telah ditunjuk sebelumnya, guna melihat sejauh mana keberhasilan yang telah dicapai serta untuk mengakomodasi semua aspirasi yang muncul dari berbagai pihak.

\section{Sistem Pembelajaran}


Sebagaimana layaknya sebuah proses belajar mengajar, pelatihan ini memiliki tujuan pembelajaran umum dan tujuan pembelajaran khusus.

\section{Tujuan Pembelajaran Umum}

Agar peserta pelatihan dapat menguasai satu atau beberapa bahasa asing yang dipakai di negara yang menjadi target operasi, dengan maksud agar peserta pelatihan mampu berkomunikasi dengan warga bangsa yang dimaksud.

\section{Tujuan Pembelajaran Khusus}

Agar peserta pelatihan dapat menggunakan "bahasa pasaran" dengan lancar yaitu bahasa yang digunakan oleh warga atau penduduk setempat yang merupakan target operasi. Ini berarti skill mendengar dan berbahasa lisan (istima' dan kalam) adalah orientasi utama dalam pelatihan ini, akan tetapi tidak melupakan skill berbahasa lainnya seperti membaca dan menulis. (Ibrahim, 2007:61)

\section{Kegiatan Belajar Mengajar}

Kegiatan formal dalam pelatihan ASTP terbagi dua, yang pertama kegiatan yang bersifat teori yang dilaksanakan tiga kali seminggu dengan durasi satu jam. Materi yang diangkat adalah bagaimana cara belajar bahasa Asing yang baik, mulai dari cara mendengar, cara berbicara, cara membaca dan cara menulis. Materi ini disampaikan oleh seorang guru. Kegiatan yang kedua adalah bersifat praktik. Kegiatan ini dilaksanakan enam kali seminggu dengan durasi dua jam. Materi yang diangkat adalah materi yang telah dipelajari, diperaktekkan sesama siswa, ditambah dengan beberapa teori kebahasaan lain. Kegiatan ini disampaikan oleh seorang native speacker dan dibantu oleh seorang guru.

Waktu yang digunakan dalam proses belajar mengajar secara formal mencapai $3+12=15$ jam dalam satu minggu, 60 jam perbulan. (Ibrahim, 2007:66-67). Untuk jelasnya kegiatan formal ASTP adalah sebagaimana jadwal berikut.

\begin{tabular}{|c|c|c|c|l|c|}
\hline No & Jenis & $\begin{array}{c}\text { Jml } \\
\text { Jam }\end{array}$ & $\begin{array}{c}\text { Tatap } \\
\text { muka }\end{array}$ & Materi & Instruktur \\
\hline 1. & Teori & 1 & $3 \mathrm{X} /$ & $\begin{array}{l}\text { Teori } \\
\text { mendengar, } \\
\text { berbicara } \\
\text { membaca dan } \\
\text { menulis yang } \\
\text { baik. }\end{array}$ & $\begin{array}{l}\text { Guru } \\
\text { Teori }\end{array}$ \\
\hline 2. & Praktek & 2 & $6 \mathrm{X} /$ & $\begin{array}{l}\text { Prakterk } \\
\text { berbicara dan } \\
\text { teori-teori } \\
\text { bahasa lain } \\
\text { yang telah } \\
\text { dipelajari. }\end{array}$ & $\begin{array}{c}\text { Speaker \& } \\
\text { Guru } \\
\text { Teori }\end{array}$ \\
\hline
\end{tabular}


Sedangkan kegiatan nonformal terbagi tiga bagian, yang pertama kegiatan dalam bentuk diskusi kelompok yang dilaksanakan dengan menggunakan bahasa target. Sementara materi yang diangkat adalah materi yang telah dipelajari, didiskusikan dalam rangka pendalaman. Kegiatan ini dilaksanakan di rauang kelas atau tempat lain yang mendukung. Kegiatan ini diawasi oleh guru.

Kegiatan yang kedua adalah berbentuk menyaksikan pertunjukan, seperti film, drama dan lain sebagainya. Kegiatan ini dilaksanakan dengan menggunakan bahasa asing. Materi yang diangkat sangat beragam sesuai dengan bahan yang tersedia. Kegiatan ini diawasi oleh seorang guru dengan menggunakan sarana yang tersedia, seperti Televisi, radio dan lain-lain.

Sedangkan kegiatan yang ketiga adalah berbentuk kuliah umum yang dilaksanakan dengan menggunakan bahasa asing.. Materi yang diangkat adalah materi yang berhubungan dengan negara tujuan, mulai dari letak geografisnya, sosial budayanya dan lain-lain. Kegiatan ini diawasi oleh seorang guru dengan menggunakan sarana yang tersedia, seperti ruangan, podium dan lainlain. (Ibrahim, 2007:66-67)

Untuk jelasnya kegiatan nonformal ini adalah sebagaimana dalam jadwal berikut.

\begin{tabular}{|c|c|c|l|c|}
\hline No & Jenis & $\begin{array}{c}\text { Bahasa } \\
\text { pengantar }\end{array}$ & Materi & Media \\
\hline 1. & $\begin{array}{c}\text { Diskusi } \\
\text { Kelompok }\end{array}$ & $\begin{array}{c}\text { Bahasa } \\
\text { Asing }\end{array}$ & $\begin{array}{c}\text { Yang sudah } \\
\text { dipelajari }\end{array}$ & $\begin{array}{c}\text { Ruang kelas } \\
\text { \& Tempat } \\
\text { lain yang } \\
\text { kondusif }\end{array}$ \\
\hline 2. & Menonton & Bahasa & Beragam & $\begin{array}{c}\text { Telivisi, } \\
\text { Radio dll. }\end{array}$ \\
\hline 3. & $\begin{array}{c}\text { Kuliah } \\
\text { Umum }\end{array}$ & $\begin{array}{c}\text { Bahasa } \\
\text { Asing }\end{array}$ & $\begin{array}{c}\text { Platform } \\
\text { negara tujuan }\end{array}$ & $\begin{array}{c}\text { Ruangan, } \\
\text { Podium, dll. }\end{array}$ \\
\hline
\end{tabular}

\section{Teknik Pembelajaran ATSP}

Untuk pertama kalinya guru menyampaikan materi dialog yang memuat \pm 30 kalimat baru. Guru menjelaskan 30 kalimat baru yang terdapat dalam dialog tersebut. Hal ini dimaksudkan agar peserta pelatihan lebih terkonstrasi terhadap materi pelajaran.

Adapun prosedurnya adalah sebagai berikut. Pertama, Guru dalam hal ini menyampaikan materi dialog dengan gaya, gerak, mimik dan lain-lain meriru gaya seorang teateris. Ini dimaksudkan agar peserta didik dapat memahami materi yang disampaikan dengan baik walaupun disampaikan dengan bahasa target, tidak menggunakan bahasa siswa. Kedua, Guru membacakan materi dialog sebanyak tiga kali. Ini dimaksudkan untuk melatih pendengaran siswa. Ketiga, Guru menyuruh siswa menirukan bacaan guru secara berkelompok, yang dimaksudkan untuk melatih mengucapkan kata-kata asing. Keempat, Guru membagi siswa kedalam dua kelompok, setiap kelompok terdiri atas lima siswa, masing-masing kelompok membentuk setengah lingkaran. Setelah itu guru menyuruh siswa secara bergantian bertanya kepada masing-masing temannya, seputar materi dialog. Seorang siswa diharuskan mengoreksi ucapan temannya yang salah, agar mereka terbiasa menggunakan bahasa yang dimaksud. Dalam hal ini, siswa sekaligus 
bertindak sebagai korektor terhadap ucapan yang ditirukan oleh teman-temannya, di samping guru yang mengawasi mereka. Kelima, Guru menyuruh siswa mempraktekkan materi dialog secara berpasang-pasangan untuk memantapkan penuturan. Keenam, Guru menerangkan ungkapan-ungkapan baru dalam dialog yang baru saja dipelajari dan menyuruh siswa menggunakan ungkapan-ungkapan baru tersebut ke dalam mufradat (kosa kata-kosa kata) lama yang telah mereka ketahui sebelumnya. Ini dimaksudkan agar kosa kata baru dapat lebih dikuasai oleh siswa tanpa melupakan kosa kata lama yang telah diketahui sebelumnya.

Beberapa rekomendasi yang perlu dicatat dalam rangka keberhasilan pelaksanaan pelatihan pembelajaran bahasa asing, antara lain adalah apa yang dikemukakan oleh Hammada Ibrahim (2007:72-73) yang memberikan beberapa catatan. Pertama, jumlah siswa dalam satu kelas tidak lebih dari sepuluh orang yang telah dikelompokkan sesuai dengan tingkat kemampuan sisiwa. Kedua, memberikan bimbingan tambahan kepada sisiwa di luar jam pelajaran yang telah ditentukan. Ketiga, memiliki instruktur/tutor native speaker, atau paling tidak seorang guru yang menguasai bahasa 'amiyah suatu negara. Keempat, hendaknya menggunakan media-media pengajaran, umpamanya media audio-visual: seperti TV, Vedio dan media lain. Kelima, menambah kegiatan-kegiatan ilmiyah di luar jam pelajaran formal, seperti studium general/kuliah umum atau kegiatan-kegiatan non-formal lainnya yang bersifat praktis dan mendukung penguasaan siswa terhadap materi yang disampaikan.

\section{Analisis terhadap ASTP}

Ada beberapa hal yang dapat disampaikan sebagai analisa terhadap proses belajar mengajar yang dilaksanakan ASTP yaitu dengan mengadakan peninjauan dari berbagai segi linguistik terapan, antara lain:

\section{Pendekatan ASTP}

Dalam pembelajaran bahasa asing para linguis menyebutkan beberapa macam pendekatan yang dapat dilakukan. Paling tidak ada empat pendekatan terhadap pengajaran bahasa yang banyak diangkat para praktisi pengajaran bahasa asing termasuk di Indonesia. Pertama, Pendekatan Struktural. Kedua, Pendekatan Humanistik. Ketiga, Pendekatan Pragmatik. Keempat, Pendekatan Komunikatif (Thu'aimah, 1989:115).

Pendekatan Struktural lebih memfokuskan pandangan terhadap bahasa sebagai satuan-satuan gramatikal dan satuan-satuan tersebut dianggap sebagai target dalam merencanakan sebuah silabus, berbeda dengan pendekatan humanistik yang lebih mengutamakan peranan dan kebutuhan-kebutuhan siswa dalam berbahasa, juga berbeda dengan pendekatan pragmatik yang lebih menfokuskan perhatian terhadap pengembangan bahasa di semua lini silabusnya Berbeda dengan tiga pendekatan di atas, pendekatan komunikatif melihat bahasa dari segi fungsinya sebagai media komunikasi dalam memenuhi kebutuhan siswanya. 
Bila diperhatikan tujuan umum maupun khusus dari ASTP; yaitu agar peserta didik menguasai bahasa sasaran, khususnya dalam berkomunikasi lisan, maka dapat diasumsikan bahwa ASTP memakai pendekatan komunikatif yang lebih melihat fungsi utama bahasa sebagai alat komunikasi dalam memenuhi kebutuhan-kebutuhan siswa. Oleh Mulijanto Sumardi mengatakan, bahwa salah satu sarat pemakaian pendekatan komunikatif adalah “...Guru seharusnya penutur asli (native speaker) dan jumlah siswa dalam satu kelas/kelompok hendaknya dalam jumlah yang sangat terbatas". (Sumardi, 1975:15)

Semua data diatas, meyakinkan bahwa ASTP memakai pendekatan komunikatif, sekalipun Muljanto sendiri tidak menentukan angka pasti berapa jumlah maksimal siswa dalam satu lokal/ kelompok.

\section{Metode ASTP}

Perkembangan metode pengajaran bahasa asing yang berkembang pada saat menjelang perang dunia ke II sudah barang tentu banyak berpengaruh terhadap kebijaksanaan yang diambil oleh ASTP dalam menentukan metode pengajaran yang akan diterapkan dalam program pelatihan yang akan dilaksanakan. Namun sebagai program besar tentu selain faktor seperti yang telah disebutkan di atas, faktor-faktor konvensional yang dapat mempengaruhi pemilihan sebuah metode pengajaran serta dasar-dasar yang harus diperhatikan dalam memilih sebuah metode sudah pasti menjadi pertimbangan mereka.

Muljanto Sumardi (1975:9) menyebutkan delapan faktor yang dapat mempengaruhi pemilihan sebuah metode pengajaran. Pertama, Pendekatan (Approach) yang digunakan. Kedua, Usia siswa. Ketiga, Latar belakang sosio-kultural. Keempat, Latar belakang bahasa sisiwa. Kelima, Pengalaman sisiwa terhadap bahasa yang akan dipelajarinya. Keenam, Perbedaan teori bahasa yang melandasinya. Ketujuh, Perbedaan pemerian diskripsi bahasa. Kedelapan, Perbedaan persepsi tentang bagaimana seseorang memperoleh kemahiran berbahasa.

Lebih lanjut, Abdul Mun'im Said Abdul 'Al (T.t.:28) menambahkan dasar-dasar yang harus diperhatikan dalam memilih metode. Pertama, metode yang dapat membuat target pengajaran jelas di mata anak didik. Kedua, metode yang dapat memberikan motivasi belajar bagi anak 
didik. Ketiga, metode yang dapat memberikan motivasi bekerja pada anak didik. Keempat,

metode yang memungkinkan anak didik mampu menilai kemajuan belajarnya. Kelima,

metode yang memungkinkan anak didik mengukur sejauh mana kemajuan yang dicapai.

Keenam, metode yang mempertimbangkan faktor-faktor edukatif. Ketujuh, metode yang dapat mengalihkan kemampuan emosional menajadi kemampuan rasional. Kedelapan, metode yang dapat mencapai target dengan upaya yang relatif sedikit. Kesembilan, metode yang dapat menghubungkan materi dengan kehidupan sehari-hari.

Para pakar pendidikan berbeda pendapat dalam menentukan metode yang digunakan ASTP dalam program pelatihan bahasa yang mereka lakukan. Sebelum melihat jenis metode apa sebenarnya yang dipakai oleh ASTP, perlu melihat terlebih dahulu bagaimana teknik ASTP mengajarkan keterampilan-keterampilan berbahasa: mendengar (istima'), bicara (kalam), membaca (qira'ah), dan menulis (kitabah).

Setiap instruktur ASTP diwajibkan memulai materi dialog (hiwar) dengan memperkenalkan terlebih dahulu cara pengucapan masing-masing kata yang tersusun rapi dalam setiap kalimat yang membentuk sebuah materi dialog. Bahkan guru diharuskan memperdengarkan bacaan tersebut minimal 3 kali. Setelah itu, guru mengajak siswa untuk mengulangi bacaan secara mandiri dan berkelompok (Ibrahim, 2007:66).

Penampilan guru yang selalu menggunakan bahasa asing (bahasa yang sedang dipelajari) dan penggunaan media audio-visual serta media-media lainnya yang telah dipoles untuk mengajarkan bahasa asing, telah memberikan warna bagi ASTP dan sekaligus merupakan ciri khasnya sebagai lembaga pelatihan yang telah berhasil menciptakan situasi, kondisi dan lingkungan (bi'ah) yang sangat kondusif bagi keberhasilan program pembelajaran bahasa asing.

Kehumanisan setiap instruktur ASTP dalam mengoreksi kesalahan-kesalahan siswa dengan cara yang refresif, telah mampu membangun kepercayaan diri setiap siswa dalam menggunakan bahasa asing dalam keseharian mereka. (Ibrahim, 2007:68)

Keterampilan membaca di ASTP diberikan secara utuh kepada siswa setelah mencapai sepertiga dari seluruh masa pelatihan. Awalnya materi bacaan yang diberikan sangat sederhana dan hanya terbatas pada sejarah, geografi, ekonomi dan budaya negara yang menjadi target ekspansinya. Di samping itu, oleh ASTP mewajibkan setiap siswa untuk menyelesaikan tugas-tugas di rumah (tamriinaat) dalam bentuk latihan menulis; kata, kalimat dan jumlah (Ibrahim, 2007:66)

Oleh karena itu, sesungguhnya ASTP tidak bisa diklaim bahwa ia tidak mementingkan keterampilan membaca, namun juga tidak bisa dipungkiri bahwa prosentase perhatian mereka 
kepada keterampilan mendengar dan berbicara jauh lebih tinggi dibanding perhatian terhadap keterampilan membaca dan menulis.

Memperhatikan krakteristik-krakteristik di atas, tampaknya metode yang digunakan di dalam ASTP mirip dengan metode langsung. Tesis ini bisa dipertimbangkan mengingat krakteristik metode langsung hampir sama dengan apa yang dilakukan oleh ASTP. (Nasution, 2002; Harahap, 2003).

Krakteristik metode langsung yang dimaksud paling tidak adalah sebagai berikut. Pertama, materi pelajaran terdiri dari kata-kata dan struktur kalimat yang banyak digunakan sehari-hari. Kedua, gramatika diajarkan dengan melalui situasi dan dilakukan secara lisan bukan dengan cara menghafalkan aturan-aturan grametika. Ketiga, arti yang kongkrit diajarkan dengan menggunakan benda-benda, sedangkan arti yang abstrak melalui asosiasi. Keempat, banyak latihan-latihan mendengar dan menirukan dengan tujuan agar dapat dicapai penguasaan bahasa secara otomatis. Kelima, aktivitas belajar banyak dilakukan di dalam kelas. Keenam, bacaan mula-mula diberikan secara lisan. Ketujuh, sejak permulaan murid dilatih untuk "berfikir dalam bahasa asing".

Metode ini didefenisikan dengan sebuah metode pengajaran bahasa, yaitu langsung menggunakan bahasa yang sedang dipelajari sebagai bahasa pengantar dan tidak menggunakan terjemah serta tidak menggunakan bahasa siswa atau mahasiswa kecuali dalam kondisi darurat (Sumardi, 1975:33).

Alasan lain mengatakan bahwa ASTP memakai metode langsung (direct method) karena ASTP ternyata melakukan beberapa kegiatan yang merupakan kegiatan unggulan dari metode langsung. Salah satu di antara kegiatan tersebut adalah kegiatan Karya Wisata. Karya Wisata sering juga disebut dengan study tour, yaitu melakukan studi kunjungan ke suatu tempat atau obyek tertentu. (Yusuf, 1995:84) Hal ini membuktikan bahwa siswa-siswa yang mengikuti ASTP juga sering melakukan survei ke negara yang menjadi tujuan mereka. (Ibrahim, 2007: 72)

Di pihak lain, aliran kebahasaan yang berkembang di Amerika sekitar tahun 1930-an dan 1940an dikenal dengan nama linguistik struktural yang dikemukakan oleh Bloomfield dan Fries. Linguistik struktural berpandangan bahwa bahasa merupakan sebuah sistem yang secara struktural terkait dengan elemen-elemen ekspresi makna. Elemen-elemen tersebut yaitu fonem, morfem, kata, struktur, dan berbagai tipe kalimat. Sistem gramatika bahasa terdiri atas elemen gramatika dan aturan-aturan untuk kombinasi linear untuk kata, frase dan kalimat.

Menurut pandangan struktural, bahasa mempunyai beberapa karakteristik. Pertama, bahasa diproduksi oleh aturan baku (cara struktural). Kedua, bahasa bisa dijelaskan secara mendalam pada setiap level struktur penjelasan. Ketiga, bahasa adalah struktur seperti pyramid yang mana level linguistik merupakan sebuah sistem dari sistem itu sendiri. Keempat, bahasa adalah percakapan bukan tulisan. Kelima, semua bahasa itu berbeda.

Berbagai pandangan tentang bahasa di atas merupakan dasar dari Metode Audiolingual, yaitu metode pengajaran bahasa asing yang menekankan pengajaran mendengar dan berbicara sebelum 
membaca dan menulis. Metode ini memakai dialog sebagai bentuk utama dalam menyampaikan bahasa dan memakai latihan-latihan sebagai tehnik latihan utama yang didukung dengan penggunaan sarana audio (dengar), seperti radio, tape recorder. Sedangkan bahasa ibu tidak dipakai selama berada di dalam kelas.

Dari keterangan di atas, tampaknya ASTP menggunakan metode audiolingual yang merupakan pengembangan dari metode langsung, sebagai buah inspirasi dari aliran linguistik struktural. Konsep ASTP ini menurut Moulton (1961) persis sejalan dengan Metode Audiolingual yang mengatakan bahwa Bahasa adalah ujaran, bukan tulisan; Bahasa adalah seperangkat kebiasaan; Ajarkan bahasa, bukan tentang bahasa; bahasa adalah apa yang diucapkan oleh penutur asli, bukan yang dianggap seharusnya diucapkan; dan Bahasa berbeda antara satu dengan yang lain. Demikian dikutip oleh Muljanto Sumardi (1975.19)

\section{Faktor Keberhasilan ASTP}

Keberhasilan metode ASTP ini, sebenarnya bukanlah disebabkan karena jenis pendekatan, metode dan teknis yang diterapkan, akan tetapi adalah karena ditunjang oleh beberapa hal, antara lain. Pertama, motivasi siswa yang sangat tinggi terhadap pembelajaran bahasa asing, dimana mereka menganggap keberhasilan dalam pelatihan ini adalah masalah hidup atau mat. Bila siswa berhasil, maka dia akan bisa hidup di negara dimana dia diterjunkan, sebaliknya bila dia tidak berhasil, maka dia akan mati di negara tempat dia ditugaskan. Kedua, disiplin siswa yang cukup tinggi, dimana disiplin militer yang diterapkan sangat keras bila dibandingkan dengan disiplin institusi sipil, hal ini sangat kondusif bagi keberhasilan setiap pembelajaran. Asumsi ini dikuatkan oleh kenyataan bahwa penerapan sistem pembelajaran semodel ASTP ini ketika diadopsi dalam pembelajaran bahasa asing untuk sivil di beberapa negara Eropah seperti Ferancis dan Yugoslavia, ternyata hasilnya jauh berbeda dari hasil yang dicapai oleh ASTP, (Ibrahim, 2007:75). Ketiga, aspek politik yang sangat menunjang dimana program ini merupakan program nasional yang dirancang sedemikian rupa untuk menopang rencana besar Amerika Serikat untuk memperluas pengaruhnya, sehingga program ini tidak mengalami kendala finansial sama sekali karena didukung oleh dana yang kuat. Keempat, kapabilitas para instruktur yang sangat tinggi turut menunjang keberhasilan pelatihan ini. Seperti diketahui bahwa Amerika Serikat tidak segan-segan mendatangkan tenaga native speacker dari seluruh belahan dunia dalam jumlah banyak (Yusis, 1995: 247).

\section{Penutup}

Metode Angkatan Bersenjata Amerika Serikat (ASTP) atau yang lebih popular dikenal dengan istilah army method sebenarnya tidaklah mengandung hal-hal yang luar biasa. Pendekatan yang digunakan adalah pendekatan komunikatif, yang sudah familier bagi banyak praktisi pengajaran bahasa asing. Demikian juga jenis metode yang dipakai adalah metode audio lingual, yang bukan merupakan barang baru bagi praktisi pengajaran bahasa asing, malah lebih maju dari itu seperti metode audio visual, metode SGAV (Structural Global Audio Visual) sudah banyak diaplikasikan. Faktor keberhasilannya kemungkinan besar adalah disebabkan faktor motivasi siswa, disiplin yang ditegakkan, dukungan dana yang kuat serta kapabilitas guru dan 
instrukturnya. Namun demikian penulis melihat program pelatihan bahasa asing semodel ASTP ini akan sangat baik bila dapat dipergunakan di pesanteren yang mempunyai asrama.

\section{DAFTAR PUSTAKA}

Abdul 'Al, Abdul Mun'im Said. Tanpa tahun. Turuq Tadris Lughah Arabiyah. Kairo: Maktabah Al Gharib.

Al-'Araby, Shalah Abd al-Majid. 2001. Ta'allum al-Lughah al-Hayyah Wa Ta'liimuha Bain alNazhryah Wa al-Tathbiiq. Bairut: Maktabah Lubnan.

Dahlan, Juhairiah. 1992. Metode Belajar Mengajar Bahasa Arab. Surabaya: Al-Ihklas.

Departemen Agama RI. 1975. Pedoman Pengajaran Bahasa Arab Pada Perguruan Tinggi Agama/IAIN. Jakarta: Depag RI.

Ibrahim, Hamadah. 2007. Al-Ittijaahaat al-Mu'ashirah fii Tadriis al-Lughah al-Arabiyah wa alLughah al-Hayyah al-Ukhraa. Kairo: Daar al-Fikr al-'Araby

Harahap, Partomuan. 2003. Metode Pembelajaran Bahasa Asing. Jakarta: Pascasarjana UIN Syarif Hidayatullah.

Pateda, Mansur. 1991. Linguistik Terapan. Flores: Nusa Indah.

Al-Qasimi, 'Ali Muhammad. 1999. Ittijaahaat Hadiitsah fii Ta'liim al-'Arabiyah li alNaathiqiina bi al-Lughah al-Ukhraa. Riyadh: 'Ummaad Syu'un al-Maktabaat.

Nasution, Sakholid. 2002. Metode Pembelajaran Bahasa Angkatan Bersenjata Amerika. Jakarta: Pascasarjana UIN Syarif Hidayatullah.

Sumardi, Mulianto. 1975. Pengajaran Bahasa Asing Sebuah Tinjauan Dari Segi Metodologi. Jakarta: Bulan Bintang.

Thu'aimah, Rusydi Ahmad. 2000. Al-Usus al-'Ammah li Manahij Ta'lim al Lughah al- 'Arabiah. Kairo: Dar al Fikr al Arabi.

. 1989. Ta'liim al-'Arabiyah li Ghairi al-Natiqina bihaa Manahijuhi wa Asaalibuhu. Riyadh: ESESCO

Yunis, Fathi Ali. 1995. Ta'lim Lughah Arabiyah, Ususuhu wa Ijra `atuhu. Cairo: Tanpa penerbit.

Yusuf, H. Tayar dan Syaiful Anwar. 1995. Metodologi Pengajaran Agama dan Bahasa Arab. Jakarta: PT. RajaGrafindo Persada. 